\title{
The mec-3 gene contains cis-acting elements mediating positive and negative regulation in cells produced by asymmetric cell division in Caenorhabditis elegans
}

\author{
Jeffrey C. Way ${ }^{1}$, Lili Wang, Jin-Quan Run, and Alice Wang \\ Department of Biology, Busch Campus, Rutgers University, Piscataway, New Jersey 08855-1059 USA
}

The homeo box-containing genes mec-3 and unc-86 are necessary to specify the fate of a defined set of mechanoreceptors in Caenorhabditis elegans. Previous experiments have shown that mec-3 expression can be divided into two phases: initial synthesis mediated in part by unc-86, and continued synthesis that requires mec-3 itself. We now identify sequences that have been conserved during Caenorhabditis evolution and are necessary for establishment, maintenance, and repression of mec-3 expression. Upstream of the start codon for the mec-3-coding sequence are four segments (regions I-IV) of 71, 29, 28, and $24 \mathrm{bp}$, which are almost identical between $C$. elegans and Caenorhabditis vulgarensis. Region $I$ is the only conserved sequence that effects establishment of mec-3 synthesis. Maintenance of mec-3 expression is mediated primarily by region II. Repression appears to be controlled by several segments: Mutation of region III, region IV, and parts of region $I$ in a mec-3-lac $Z$ fusion results in $\beta$-galactosidase expression in some non-mec-3-expressing sisters of mec-3-positive cells. These results indicate that the mec-3 $5^{\prime}$ region contains target sequences that mediate a genetic switch between alternative fates expressed by sister cells in a stereotyped cell lineage.

[Key Words: mec-3; C. elegans; autoregulation; asymmetric cell division; unc-86; lineage]

Received August 12, 1991; revised version accepted September 12, 1991.

Mechanisms for choosing between two differentiated states are found throughout development. A $\lambda$-infected Escherichia coli cell can develop along a lytic or lysogenic pathway. Each fate is controlled by a distinct DNA-binding protein, $\lambda$ repressor or Cro, whose expression is mutually exclusive (Ptashne 1987). The choice between the two sexual states in Drosophila is controlled at the level of RNA splicing, rather than transcription. The initial synthesis of Sex-lethal protein is controlled by the $\mathrm{X}$-to-autosome ratio. Once this protein is synthesized, it modifies the pattern of its own splicing so that a coding form of mRNA is generated (Bell et al. 1988). In both of these examples, there is a protein whose expression represents commitment to a particular fate: $\lambda$ repressor or Sex-lethal. Each protein has a distinct establishment phase of synthesis and is then necessary for the maintenance of its own expression. If synthesis of these regulatory genes is repressed or never established, an alternative fate is chosen.

Development of Caenorhabditis elegans is characterized by repeated cell divisions in which two sister cells

${ }^{1}$ Corresponding author. acquire different fates. To understand this process, we are studying mec-3, a homeo box-containing gene that is expressed in three sets of mechanoreceptors and appears to control their identity, thus playing a role similar to $\lambda$ repressor or Sex-lethal. mec-3 also has establishment and maintenance modes of synthesis. In a wild-type $C$. elegans strain carrying a mec-3-lac $Z$ fusion, the fusion is expressed throughout development after each mec-3synthesizing cell arises (Fig. 1A), whereas in a mec-3 mutant, a mec-3-lac $Z$ fusion is expressed in the correct set of cells but only transiently after each cell is produced. Thus, the mec- 3 product is proposed to be necessary for its own continued expression (Way and Chalfie 1988, 19891.

The unc-86 gene is necessary for the production of mec-3-expressing cells and for the production and differentiation of many other neurons in C. elegans /Chalfie et al. 1981; Way and Chalfie 1989; Finney and Ruvkun 1990). In unc-86 mutants, patterns of cell division and differentiation are altered so that in place of mec-3-expressing cells and their sisters, other cell types or incorrectly differentiating cells are produced. The unc- 86 protein is expressed in each cell that is a parent of a mec-3expressing cell; and after this cell divides, unc-86 is 
Figure 1. Cells that can express mec-3lacZ in C. elegans. (A) Schematic diagram of $C$. elegans showing cells that normally express mec-3 (solid ovals; Way and Chalfie 1989) and additional cells (open ovals) that express mec-3-lac $Z$ from plasmids with alterations in the mec-3 promoter (see Tables 1 and 2 ). (B) A young L2 animal carrying pR4delA-Z (jeEx8), seen from the dorsal aspect. This animal shows expression in the SDQR and SDQL cells in the middle of the animal and in the ALNR cell in the tail, as well as having $\beta$-galactosidase activity in most of the normal mec-3-expressing cells. (The PVD neurons have not arisen by this stage of development. This particular animal appears to be a genetic mosaic that has lost the jeEx8 element from PLML and ALNL.)(C) The tail of an $\mathrm{L} 2$ animal carrying pR4delA-Z, viewed from the left side, showing $\beta$-galactosidase activity in the PLM cells and their sisters, the ALNs.

detectable in both the mec-3-expressing cell and its nonmec-3-expressing sister (Fig. 2). In an unc-86 mutant, mec-3 is never expressed, which may be the primary reason why subsequent mechanoreceptor differentiation does not occur. unc- 86 is thus necessary for establishment of mec-3 expression.

The role of mec- 3 in terminal differentiation is best understood for the six touch receptor neurons, which are a subset of the mec-3-expressing cells /Chalfie and $\mathrm{Au}$ 1989; Way 1990; Wolinsky and Way 1990). Mutations in mec (mechanosensory) genes cause defects in the touch receptors, so that mutant animals are insensitive to a gentle touch with an eyebrow hair. mec-1, -2, and mec-

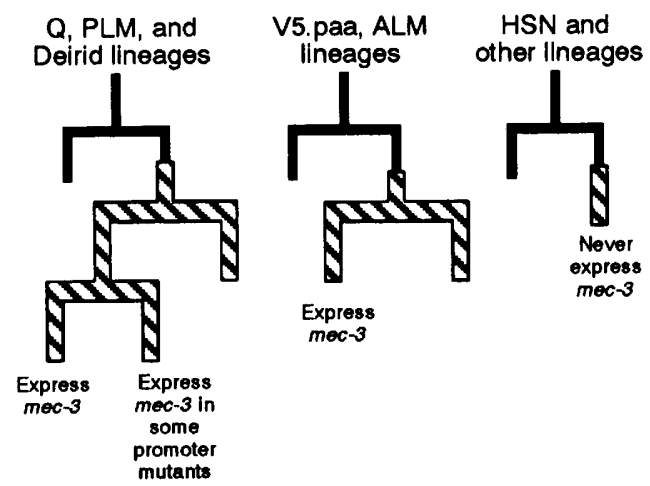

Figure 2. Relationship between mec-3 and unc-86 expression in C. elegans. Some unc-86-expressing cells (hatched regions) divide several times to produce sets of related cells that contain this protein. At most, one daughter of such a cell will express mec-3: This cell is always an anterior daughter. Other cells express unc-86 after the final cell division: These cells never express mec-3 (Way and Chalfie 1989; Finney and Ruvkun 1990). These results suggest that a cell must go through a division cycle while expressing unc-86 to express mec-3. Some alterations of the mec-3 5' region cause expression in the posterior sisters of a subset of $m e c$-3-expressing cells. These changes may disrupt the control of asymmetric expression of mec-3. (The cases of ectopic expression all occur in lineages in which the unc-86-expressing cell divides twice before mec-3 is expressed, the significance of which is unclear.)
4-17 are necessary for the function of the touch receptors, whereas $m e c-3$ is necessary for the overall differentiation of these cells. Two genes in the former class have also been cloned: mec-7 is a touch receptor-specific $\beta$-tubulin (Savage et al. 1989; M. Hamelin, I. Scott, J. Way and J. Culotti, in prep.|, whereas mec-4 encodes an apparent membrane protein (Driscoll et al. 1991). mec-3 may directly turn on genes such as mec-4 and mec-7. In the other cells in which mec-3 is expressed, analogous "downstream" genes have not been identified. The sisters of the $10 \mathrm{mec}-3$-expressing cells do not synthesize mec-3 (except perhaps transiently after they are produced; Fig. 1B; see below) and are unaffected in mec-3 mutants (Way and Chalfie 1989). mec-3 is therefore a plausible candidate "switch" gene whose expression represents commitment of a cell to a particular developmental program.

To understand how mec- 3 is expressed in only one cell after an asymmetric cell division and only upon termination of cell proliferation, a detailed analysis of control sequences in the mec-3 promoter has been initiated. The results that follow indicate that the mec- $35^{\prime}$ region includes discrete sequences for establishment and maintenance of mec-3 synthesis, as well as regions for repression of mec-3 in the sisters of cells that normally express this gene.

\section{Results}

Isolation of a mec-3 homolog and identification of mec-3 sequences conserved during evolution

Candidate sequences in the mec-3 gene that could regulate its expression were initially identified by a comparison of the mec-3 gene from two species. This revealed several conserved noncoding sequences. Such sequences are presumed to be conserved because they are positively selected during evolution.

Using low-stringency cross-hybridization, an apparent mec-3 homolog from Caenorhabditis vulgarensis (C. Link, pers. comm.) was identified. This species is similar to $C$. elegans in size, appearance, and behavior. C. vul- 
garensis also has a touch response like C. elegans, suggesting that it would have touch receptor neurons and a mec-3 homolog to control their development. The plasmid pJW91-1 (Fig. 3A), which carries a 3.0-kb DNA fragment from $C$. vulgarensis that cross-hybridizes with $C$. elegans mec-3, can rescue $C$. elegans strains carrying the mec-3 alleles $u 6$ or $u 298$ upon microinjection (see Materials and methods), indicating that this DNA corresponds to mec-3 itself and not a functionally distinct gene.

The 3.0-kb fragment from $C$. vulgarensis contains sequences corresponding to all of the exons of $m e c-3$ in $C$. elegans (Fig. 3A). Comparison of the two sequences indicates that the first two mec-3 exons proposed by Way and Chalfie (1988) are incorrect and that the correct protein sequence of $C$. elegans mec-3 corresponds to that shown in Figure 3B. This interpretation of the coding sequence is consistent with that proposed by Freyd et al. (1990) because of the similarity of mec-3 to the lin-11 protein sequence. The amino acid sequence of the mec-3 protein from the two species is $91 \%$ identical (Fig. 3B).

Intron sequences appear to be completely unrelated between the two species. For example, the first intron in C. elegans mec-3 is 496 bp in length, whereas in C. vulgarensis this intron is only $73 \mathrm{bp}$ long. The lengths of the other introns are also not conserved, except for the short intron within the homeo box, which is 44 bp in C. vulgarensis and $43 \mathrm{bp}$ in C. elegans. Within this intron, 11 of $31 \mathrm{bp}$ between the donor and acceptor sites can be aligned.

Upstream of the coding sequence are four long stretches of conserved bases (regions I-IV), as well as several shorter regions of similarity (Fig. 4A). Regions I-IV are $71,29,28$, and 24 bp long, respectively. These regions may include binding sites for the unc-86 and mec-3 proteins which, on the basis of genetic evidence, are known to regulate mec-3 (Fig. 4B; Way and Chalfie 1989). unc- 86 is a member of the POU family of homeo domain proteins (Ruvkun and Finney 1991). From the known binding sites of other members of this family, the consensus CAT-T/AT/AATNCAT has been derived, which is similar to the sequence CATNNGAAATGCAT that occurs at the $5^{\prime}$ side of both regions I and II (Fig. 4B). The mec-3 protein sequence is related to that of the pancreatic islet transcription factor Isl-1, which binds to the sequence TTAATAATCTAA in the insulin gene (Karlsson et al. 1990). A closely related sequence, TTAATAATCGAT, is found in region III, and a somewhat less related sequence, TCTATTATCGTC, is found in region II. However, because only one binding site for any member of the LIM family of proteins has been identified, the significance of the latter sequence relationships is unclear.

In the last intron of $C$. vulgarensis mec-3, there is a small region (base pairs 2442-2532), immediately $5^{\prime}$ to the last exon, that is similar to the corresponding region in mec-3 of C. elegans. In this region, 63 of 91 bases are identical (with two gaps in the alignment), and it includes one stretch of 18 identical base pairs. This sequence might be important for RNA processing or some other function that determines the absolute level of mec-3 synthesis but does not appear to be involved in cell-specific regulation of mec-3 (see below; data not shown). This conserved region has not been studied further.

\section{Function of regions $I-I V$ in mec-3 regulation}

To determine the function of conserved noncoding regions, various parts of $m e c-3$ from a mec-3-lacZ fusion were mutated or deleted, and effects on expression of $\beta$-galactosidase in C. elegans were examined (Table 1). To confirm some assignments of function to certain sequences, the same mutations were introduced into an otherwise intact $m e c-3$ gene to examine the effect on its ability to rescue a mec-3 mutant (Fig. 4). With a wildtype mec-3-lacZ fusion (pTU28/uEX4, where pTU28 is a $m e c-3-l a c Z$ fusion plasmid and $u E x 4$ is the extrachromosomal array derived from it; Table 1 ; Way and Chalfie 1989), $\beta$-galactosidase synthesis is seen in only 10 cells in C. elegans. Expression is first seen after the final division that produces these cells (Fig. 2), and can be observed for the remainder of development. Of the constructs described below, some give a staining pattern identical to the wild-type pattern, some show no expression or expression that is uniformly reduced across all stages in each cell type, and some show regulatory defects in establishment, maintenance, or repression (Table 1; Figs. 1 and 4). For all of these constructs, the 10 mec-3-expressing cells appear to be affected equally: There are no constructs that cause a significant reduction in a subset of cells. None of the plasmids cause expression in any other cell type besides the normal cells or their sisters.

If sequences outside the conserved upstream regions are deleted (upstream to base pair 1494 and downstream from base pair 1968) there is no observable effect on expression of a mec-3-lac Z fusion (pUpsA-Z in Table 1; data not shown). In addition, sequences up to base pair 1494 can be removed without affecting the ability of an intact mec-3 gene to rescue the mec-3 mutants $u 298$ or u6 (Way and Chalfie 1989; data not shown).

Regions I, II, and III are sufficient to mediate expression in the $10 \mathrm{mec}$-3-expressing cells when coupled to heterologous promoter elements. To test the conserved regions in the mec-3 promoter for enhancer activity, restriction fragments containing parts of the mec-3 upstream region were fused to a C. elegans HSP16-41 heat shock promoter (Fig. 5; Jones et al. 1986). pR123-HS contains regions I, II, and III (base pairs 1418-1870) fused to a single heat shock enhancer element, the heat shock TATA box, followed by $1 a c Z$ and a 3 '-end region from the $C$. elegans myosin heavy-chain gene unc-54.

C. elegans that carries pR123-HS does not express detectable $\beta$-galactosidase activity unless it is heatshocked, whereupon lacZ expression can be seen only in the $10 \mathrm{mec}$-3-expressing cells. Apparently the activity of either the mec-3 or heat shock enhancer alone is insufficient to stimulate detectable lac $Z$ expression, but the two sets of enhancers must be active in the same cell at 
A.

GAATTCCATAAAGTTTGACTACACGAACAAGTGAAGATTGTCAGTTTTTTGCTTGACAAC GTGCCCCCAGAATCCCTTTTTTTAACAAATGTTTGTTAGCTCCTGCAAAACGGATTGATTG TTGATTTCTATTCTTTTCTCTCAAAAAAAAACTTCGACGCCCTTTTCTCTCCCAATTTTG GAAAACAAACTCTCCCCGTTTCCCATTCGAAATGCATTGTCCATAATGGATCGACCGAAA AACAGAAGTGACCAGGCGTCAGGTGATCGATAGACGAGACTTCTCTTCTTTCTCCAGAAG CTGTTCCTTAACTTTTTCTCTCTTACTTCATCGGAAATGCATCTATTATCGTCACTTCTT CCCATTTCTCGCCCCCAGTTTTAGCGCACATTAATAATCGATGGGTGGATAGTGGGGACC CATTGGATAAGATGGCGAGAAGGGACACGCCTACTTTIGTCATCTGGAGACGACGAAGAC TGACGGGTGATITGTTACGGTGAGAAAGTGAGTGAGAGCTGCTGTTGTTGCTTATACACA MetGluLeuLeugluserLy
CCCTCATTICGCGCATTTCACAAATCTGGAGAGATGGAGTTGCTCGATCGAAGCATT 600

SerAlaIleserMetValI leaspserIleGlyvalAspHisAspserGin GAGTGCTATTAGTATGGTTATTGATICGATTGGAGTGGATCATGATAGTCAGGTAGGTCA 660 AAACAATTATTGGGGGAACATTTGGGCGCATTGGTTACTATTACTTCAAAGCATTCATT 720

AsnLYSCYSAsnCY BCYsABnGluGlnI leTyraspargP he I leTyrArg TCTAGAACAAGTGTAATTGCTGCAATGAGCAAATTTACGATCGTTTCATTTATCGAGTAA 780 GTCGAGTAGCTTCTTGTTGGTCGTTTTTTTGACTCGTATCACTTTTCTGCTTCTGTATTT 840

MetaspasnargserTy

TTCCTTCATGCATCACATCAACTCAAAACGAGAATTTTTTCCAGATGGACAACCACTCAT 900

HisGluAsnCysVallysCys ThrI leCysGluserProleuAl GluLysCy\&PheTrP ATCATGAAAACTGTGTGAAATGTACAATCTGTGAGTCCCCGTTGGCAGAGAAATGTTTCT 960

LYBABnGLYArgIleTYrCYsSerGlnHIBTy TyrLYs

IYAAT 1020 TGGCTACGGGTCGTTTTGGATTCACAGATTCTGGAGTTGAGACTATGTCGATTTCAAACG 1080 GTGTTGTTACAAAATTTTTGGGTCAAAATGACTCTTAGTCGAGCTTGCTGCTCTGAATT 1140

AspHisserserHisArgCysalaGlyCysLysLysGl TCTACCTCTACTTGAGTTCAGGGATCACAGCTCTCACAGATGTGCCGGTTGCAAGAAGG 1200

ValserproThrAspMetValTy

GAGTCTCACCAACCGACATGGTTTACAAGTTGAAGGTAAATAACGGTTACTGTCCTTTAA 1260

AlaglyLeuvalpheHisvalgluCysHi AGTTCAGTTTICCATCTITGAAACATTTCCAGGCAGGCCTAGTCTTCCACGTAGAATGCC 1320

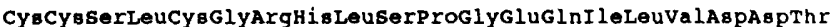
ACTGTTGCTCTCTITGTGGTCGTCATCTGTCTCCCGGAGAACAAATCTTGTCGATGACA 1380

MetMetThrvalserCysMetThrH1 TyrProproglnMetAspaspserCysGlypro CCATGATGACCGTATCCTGCATGACCCATTACCCACCTCAAATGGATGATTCTTGTGGTC 1440

ProAlaglyThrsergluvalprosercysserserAspserserI lealaproTyrPro CACCTGCTGGAACATCTGAAGTTCCATCATGTTCCTCTGACTCTGCAATCGCCCCCTACC 1500

MetAspgluglyPheProserAlapheGlnvalLys Lys

CCATGGATGAAGGGTTCCATCTGCATTCCAAGTTAAAAAGGTAAAGCAAATTCTATTTT 1560

GluValAspalaTyrGlyTy rAsnPheGlu

TGAGCAAATTATAAAACATCATCTTATTTCAGGAAGTCGATGCATACGGATACAATTTTG 1620

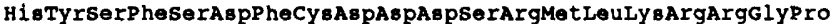
AGCACTATAGCTTCTCTGATTTTTGCGATGATGATTCCCGGATGTTGAAGAGAAGAGGGC 1680

ArgThrThrI leLYgGlnagngln

CGAGGACAACGATCAAACAGAACCAAGTAAGAGGACCTAGATCTAGATATGGTAAATGCA 1740

LeuAspValLeuAsngluMetPheserAsnThrP roLysProserLysHis

TAAGTTCCAGCTTGACGTTCTTAATGAGATGTTCTCAAACACCCCGAAGCCTTCGAAGCA 1800

AlaArgalaLy LeuAlaLeugluthrGlyLeuserMetargval IeglnvalTrpPhe TGCCAGAGCAAAGAAGGCATTGGAGACTGGGTTAAGCATGAGAGTGATTCAAGTATGGTT 1860

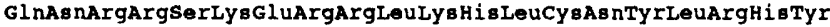
CCAGAATCGGAGAAGCAAGGAGAGAAGACTAAAGCATTTGTGCAATTATTTGAGACATTA 1920

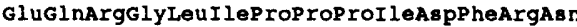

TGAGCAGAGAGGACTCATTCCGCCTCCAATTCATTTCAGAAATGGTGAGTGTACTGTAAC 1980 TTGAGTTGCCGTGCTTAAATTCGGTACCGATAGTATAAAAGCCCGTCAGAATAGGAACTA 2040 CTTTAGTCAGAAAGCCCGAACCCGGCTAATAATGTTGGCATGTTTCATCATATACAACAT 2100 CTITAGTCAGAAAGCCCGAACCCGECTAATAATGTTGGCATGTTTCATCATATACAACAT 2100 D AATCCAACCAGGGCGATACCITCITCCATGGIATGGGCAAGTHGCCCAATCCCTGCCCG 2220 AAATITCITGITITA AAAGCTCTCTCACAAATTCAAATACTCAAAATGTCAAACTICCTTCAAATCACCACCAAC 2340 CACTCTTIAATTAGATTACTCCACGTAAATCTITITGAAAAGCCTCCACTITAGTCGTTT 2400 CGGAGCCAAAAGACTAGACATAAAAAGGAAAAAGAGGATGACGTAAAAAAAGAAAATGAA 2460 AAAGAAGTTTTGACTTGCCACGTCATAAATCAGCCGTACCAAATGGCATCTCTACTCTCC 2520 GluglumetaspThrThr

TTTTGCTCTTCTTTTCTCCACTTCAACCACTAGTTTTTTTCAGAGGAAATGGACACAACT 2580

AspPheAsnSerPheCYsGlyAsnPheGluGluGluAspAspGluAsp--

GACTTCAACTCATTCTGCGGAAATTTCGAAGAGGAAGATGATGAAGATTGATTTATTTAT 2640 TGTTCCGAGTCTTTTATTACCTAAACATTTATTTCCAAAAAGTMTCCCTTTTTCTTCGAT CGCGTGACT CGGGGGAACTCICAACTCACACTAATAGGGTCGT 2820 TAATITTTTTETITTCATAGTCTTCATGCATTCTCTTGAGGCTGTAGTTTTCAGAACGG 2880 TGAGATTGTTTTCCTATTGTATAG 2940 TITTTATCAAATTATAATGTTAGTGGAACGTCACTCATATAGTTACAGTAAAACAAATGC 3000 TATTTCAGAATTG'TTTCACCATTAAAAAATGATTGGTTGCGACTACAAATTGACCAATTT 3060
TTTGATCGTAAAACAGTGATTC
MELLESKPLSAISMVIDSIGVDHDSQ

Exon 1

NYCNCCNEOIYDRFIYR

Exon II

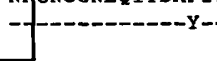

1 st LIM repeat

MDNRSYHENCVKCTICESPLAEKCFWKNGRIYCSQHYYK

Exon III

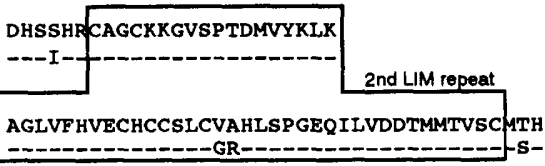

Exon IV

YPPQMDDSCGPPAGTSEV PSCSSDSSIAPYPMDEGFP

- - - - NAPGAI-SAVDI_---TENP--_--I--S-S

Exon V

AFEVKK

----

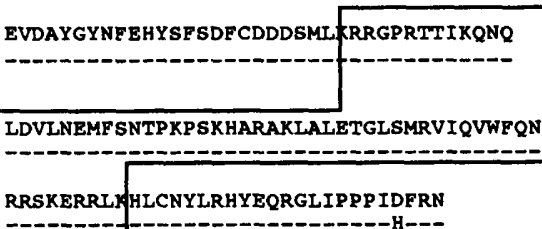

Exon VI

Exon VII

EEMDTTDFNSFCGNFEEEDDED

Exon VIII

Figure 3. $(A)$ The sequence of the mec-3 gene from $C$. vulgarensis (the insert from pIW91.1). This region contains an intact mec-3 gene, as defined by its ability to rescue the $C$. elegans mec-3 mutants $u 6$ and $u 298$. The coding sequences shown are inferred from comparison with the $C$. elegans sequence. $(B)$ Alignment of the mec-3 protein sequences from $C$. vulgarensis (top) and $C$. elegans (bottom). The mec-3 protein sequence can be divided into three regions: a cysteine- and histidine-rich LIM region consisting of two LIM repeats (Freyd et al. 1990), a homeo domain, and an acidic region encoded by the final exon (Way and Chalfie 1988). The sequence alignment shown here sug gests that the first two C. elegans mec- 3 exons are at base pairs 2021-2098 and 2494-2544 and are shown incorrectly in Way and Chalfie (1988).

the same time and can "cooperate" to mediate $l a c Z$ transcription. This type of cooperativity is a common property of enhancers (Kakidani and Ptashne 1988; Webster et al. 1988) and does not suggest anything unusual about the mec- 3 or HSP-16 regulatory sequences. This result indicates that a restriction fragment carrying conserved regions I, II, and III can cause cell-specific transcriptional activation in mec-3-expressing cells.

\section{Establishment of mec-3 expression}

Sequences including region I, but not regions II, III, or IV, are necessary and sufficient for establishment expression of mec-3. A mec-3-lac Z fusion that lacks region I and upstream sequences does not express $\beta$-galactosidase activity in a mec-3-independent manner (pRldelA-Z, Table 1; Fig. 4D). However, this region I $-\mid$ mec-3-lac $Z$ fusion is still expressed in a mec-3 $1+\mid$ strain, indicating that region I is not required for maintenance of $\mathrm{mec}-3$ expres- 


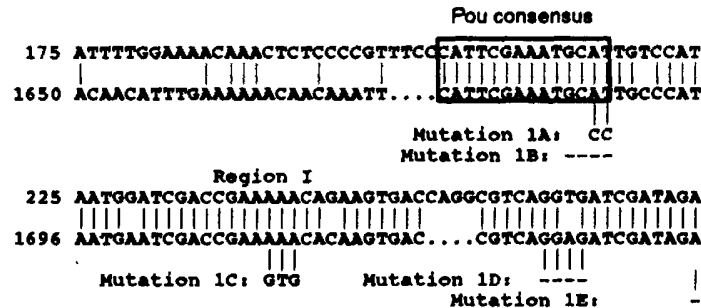

$\begin{array}{ccc}\text { B Region I } & \text { CATTCGAAATGCAT } & \text { unc-86 } \\ \text { Region II } & \text { CATaagAaATGCAT } & \text { targets? } \\ \text { POU Consensus } & \text { CAT-D-TTATNCAT } & \\ & \text { AA }\end{array}$

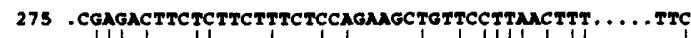

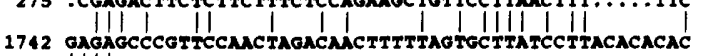

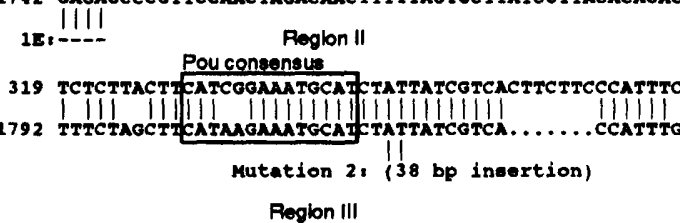
369 TCGCCCCCAOTTTTAGCGCACATTMATMATCGATGGOTOGATAGTGOGGA

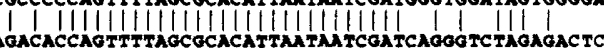
Mutation 3: IIIII!

119 CCCATTGGATAMGATGGCGAGAGGGACACOCCRACTtTTGTCATCTGGA

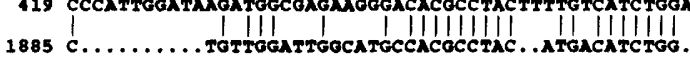
Region IV

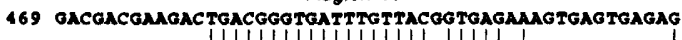

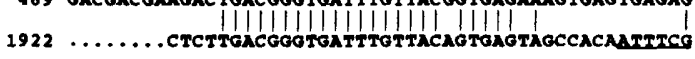

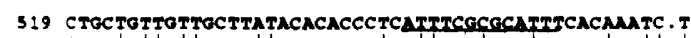

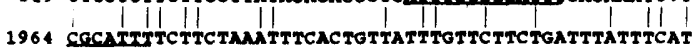
start codon 568 GGAGAGAATGGAGTTGCTCGMATCGMACCATTGAGTGCTATTAGTATGO

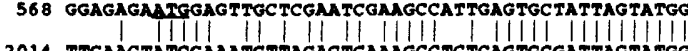

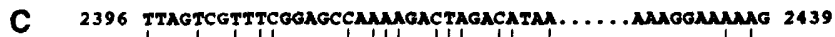

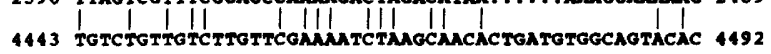
2440 AGGATGCGTMNMNAGMAAATGMNAAGMGTTTTGACTTGCCACGTC 2489

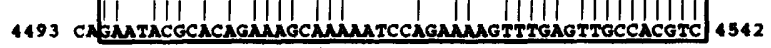
Conserved regions in final intron

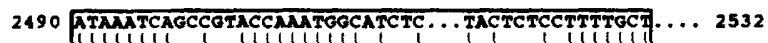

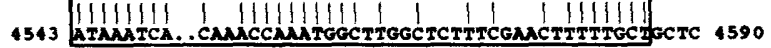
Final exon -> 2533 .... CTTCTTTTCTCCACTTCAACCACTAGTTTTTTRCAGAGGMATGGA 2578

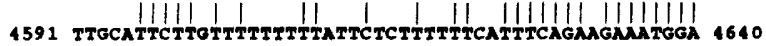
2579 CACANCTGACTTCACTCATTCTGCGGMATTTCGAMAGGMAGATGATG 2628 2579 CACAACTGACTTCAACTCATTCTGCGGAATTFCGAaGAGGAGATGATG 262

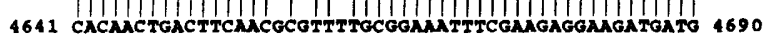
Stop

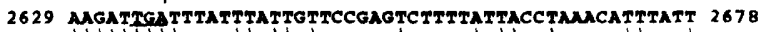

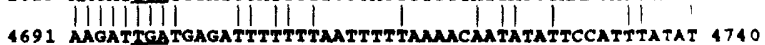

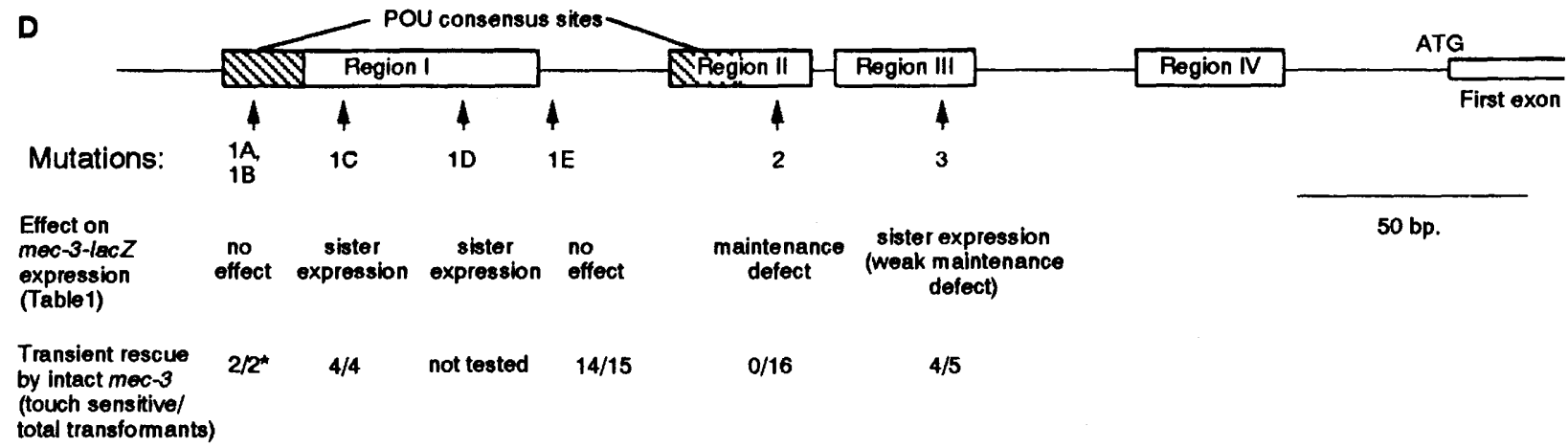

Deletions

pR1+2-Z: no expression
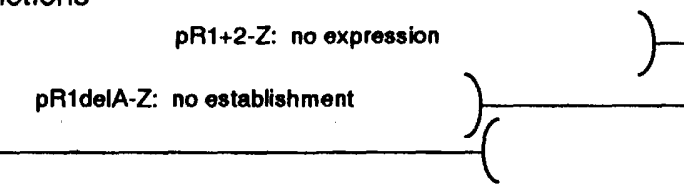

pR1-HS: establishment, no maintenance

pR4delA-Z: sister expression

Figure 4. Regions of similarity between the mec-3 5' regions from C. elegans and C. vulgarensis and their functions. $(A)$ Computer alignment of mec-3 $5^{\prime}$ regions from C. vulgarensis (top) and C. elegans (bottom; Way and Chalfie 1988). Vertical lines show identical base pairs. In addition, a 13-nucleotide region of identity found between region IV and the start codon is underlined (base pairs 546-568 in C. vulgarensis and 1958-1970 in C. elegans), as is the start codon. Alterations introduced into the C. elegans intact mec-3 gene or mec-3-lacZ fusion are also shown. $(B)$ Relationship of conserved mec-3 $5^{\prime}$ sequences to target sites for POU proteins (Ruvkun and Finney 1991). Because unc-86 is a member of this family, it may bind to these sequences. $(C)$ Computer alignment of conserved regions within the final intron of $m e c-3$ from $C$. vulgarensis and $C$. elegans. $(D)$ Effects of mutations and deletions of conserved upstream regions on expression of a mec-3-lac $Z$ fusion or on the ability of an intact mec-3 gene to rescue the mec-3(u6) mutant. Transient rescue by intact mec-3 shows the ability of each construct, when injected into mec-3(u6) with the Roller plasmid pRF4, to rescue touch receptor function: Shown is the number of touch-sensitive animals over the total number of Rollers identified among progeny of injected animals. The parent of the intact mec-3 plasmids described here is pTU48 (Table 2 ; for construction, see Materials and methods). For the deletions shown, the lines represent DNA that remains in a construct. (*) Only plasmid pR1B-I was tested. 
sion. Compared with a nonmutant mec-3-lac $Z$ fusion, $1 a c Z$ from $\mathrm{pR} 1 \mathrm{del} \mathrm{A}-\mathrm{Z}$ is expressed at a reduced level. Sequences removed by this deletion may play a role in determining the overall level of mec-3 transcription.

A DNA fragment containing only region I can mediate transient gene expression in mec-3-expressing cells after these cells arise, suggesting that region I is sufficient to direct establishment but not maintenance synthesis of mec-3. The plasmid pR $1-\mathrm{HS}$ contains a mec-3 restriction fragment with only conserved region I fused to the $C$. elegans HSP16-41 heat shock promoter (Fig. 5). This construct is similar to $\mathrm{pR} 123-\mathrm{HS}$ except that it lacks regions II and III. Like pR123-HS, the mec-3 and heat shock promoter elements are insufficient by themselves to induce transcription but appear to cooperate when both are active.

When C. elegans carrying pR1-HS are heat-shocked, $\beta$-galactosidase activity can be seen in the postembryonic AVM, PVM, and PVD neurons shortly after these cells arise but not at later times. In a mixed population of L1-L4 larval animals carrying pR1-HS, 8 of 60 showed expression in either AVM, PVM, or one or both PVDs. Only animals at $\sim 11-14 \mathrm{hr}$ of postembryonic development show expression in AVM or PVM. Because the heat shock is for $1 \mathrm{hr}$, followed by a 2 -hr recovery, this result suggests that the regulatory elements that mediate mec-3 establishment are active at $\sim 8-11 \mathrm{hr}$ of development, which is about the time that these cells arise (Sulston and Horvitz 1977).

We interpret these results by assuming that the conserved regions can function as enhancers. Other models are formally possible, but all would require that region I respond to signals present only in the mec-3-expressing cells around the time they are generated.

Mutation of the POU consensus site within region I does not affect establishment of mec-3 expression (pR 1B$\mathrm{Z}$, Table 1). It is possible that other nonconserved sequences upstream of region I can also mediate establishment, that mutation lB does not abolish function of this site, or that unc-86 does not act through this site.

\section{Maintenance of mec-3 expression is mediated primarily by region $I I$}

A mutation in region II causes a mec-3-lacZ fusion to be expressed in a wild-type $C$. elegans strain in the correct set of cells for only a short period after they arise, after which all expression is lost (pR2-Z, Table 1). This pattern is the same as that seen for an intact mec-3-lacZ fusion in a mec-3 mutant background (Table 1, Way and Chalfie 1989). In addition, an otherwise intact mec-3 gene with a region II mutation cannot rescue a mec-3 mutant (Fig. 4). A deletion that removes both region I and part of region II (pR1 + 2-Z, Table 1 ) prevents all expression, suggesting that both establishment and maintenance expression have been abolished.

A region II mutation in the chromosomal mec-3 gene is defective in maintenance of touch receptor function. The mec-3 mutation $u 298$ has a transposon Tcl insertion in region II of mec-3. Most u298 young larvae are detectably touch sensitive, whereas animals carrying the strong mec-3 allele $u 6$ newly hatched larvae are touch insensitive throughout development. In one experiment in which animals $<4 \mathrm{hr}$ old were tested for touch sensitivity in the tail, 48 of 70 u298 larvae and 4 of $61 u 6$ larvae responded to this stimulus. In later stages, touch sensitivity is completely absent in both mec-3 mutants (J. Way, unpubl.; Chalfie and Au 1989). It thus appears that in u298 animals, mec-3 is expressed transiently in the PLM neurons and mediates their differentiation into touch receptors. However, mec-3 synthesis is not maintained, so synthesis of touch receptor-specific structural genes is discontinued; and as the animal and the touch receptor grow larger, the cell can no longer function.

Together, these results indicate that alteration of region II causes a defect in mec-3 maintenance, which is mediated by $m e c-3$ itself. If such a mutation alters mec-3 action upon itself, then the level of $l a c Z$ expression in a mec-3 (-); mec-3-lacZ (region II -) strain should be the same as in a strain that is mutant only in mec-3 or region II. Alternatively, if the mutation in region II somehow simply causes an overall reduction in expression of mec3-lacZ fusion, or an array carrying such a construct is somehow defective, then a chromosomal mec-3 mutation should further reduce expression of the fusion. The first possibility appears to hold: When the mec-3-lacZ fusion carrying a region II mutation is crossed into a mec-3(u6) background, its expression level is not reduced and is no less than that of a nonmutant fusion [Table 1 , cf. pTU28; mec-3(u6), pR2-Z, and pR2-Z; mec-3(u6)]. This implies that the alteration in region II interferes with the action of mec-3 on its own promoter. [In fact, expression from the mec-3-lacZ (region II-) fusion is somewhat higher in mec-3(u6) than in mec-31+); we have no explanation for this result.]

Region II contains a POU consensus site, suggesting that unc- 86 might bind to this region, but thus far genetic data failed to show a role for unc-86 in the continued expression of $m e c-3$. The temperature-shifting of the unc-86-ts mutant, $n 848$, after the establishment phase of mec-3 expression has no detectable effect on either touch sensitivity or expression of the wild-type mec-3lacZ fusion. (M. Finney, pers. comm.; J. Way, unpubl.).

A mutation in region III may have a weak effect on maintenance of mec-3-lacZ fusion expression (pR3-Z in Table 1). Mutations in region I or region IV have no effect on maintained expression (Table 1).

\section{Sequences for repression of mec-3}

Mutations in region III, region IV, and some sites in region I all cause expression of mec-3-lac Z fusion in some sisters of the normal mec-3-expressing cells. Staining of these cells is seen most dramatically after the cells arise and gradually decreases during development. In $\mathrm{L} 1$ and L2 larvae, $\beta$-galactosidase expression can be seen in the ALN, SDQ, and AIZ neurons, which are sisters of the PLM, AVM/PVM, and FLP cells, respectively (Fig. 1; Sulston et al. 1983; data not shown). AIZ and SDQ can be identified by their position in DAPI-stained animals, 
Table 1. Expression of mec-3-lacZ fusions in the embryonic ALM, PLM, FLP, and PLM sister (ALN) neurons at different stages of C. elegans development

\begin{tabular}{|c|c|c|c|c|c|c|c|}
\hline \multirow[b]{2}{*}{ Plasmid } & \multirow[b]{2}{*}{$\begin{array}{l}\text { Host } \\
\text { genotype }\end{array}$} & \multicolumn{6}{|c|}{ Stage of development } \\
\hline & & Ll larvae & L2 larvae & L3 larvae & L4 larvae & $\begin{array}{l}\text { young } \\
\text { adult }\end{array}$ & $\begin{array}{l}\text { gravid } \\
\text { adult }\end{array}$ \\
\hline \multicolumn{8}{|c|}{ Nonmutant elements } \\
\hline pTU28(uEx4) & $\operatorname{mec}-3(+)$ & & & & & & \\
\hline ALM, PLM, and FLPs & & $63 \%(96)$ & $83 \%(54)$ & $69 \%\{54\}$ & $67 \%(30)$ & $72 \%(18)$ & $71 \%(24)$ \\
\hline Putative PLM sisters & & $0 \%(32)$ & $0 \%(18)$ & $0 \%(18)$ & $0 \%(10)$ & $0 \%(6)$ & $0 \%(8)$ \\
\hline pTU28(jeln2) & mec-3(+) & \multicolumn{6}{|c|}{ Experiment A } \\
\hline ALM, PLM, and FLPs & & $74 \%(114)$ & $61 \%\{36\}$ & $60 \%(42)$ & $61 \%(18)$ & $60 \%(30)$ & $69 \%(36)$ \\
\hline Putative PLM sisters & & $0 \%(38)$ & $0 \%(12)$ & $0 \%(14)$ & $0 \%\{6\}$ & $0 \%(10)$ & $0 \%(12)$ \\
\hline pTU28(jeln2) & mec-3(+) & \multicolumn{6}{|c|}{ Experiment B } \\
\hline ALM, PLM, and FLPs & & $76 \%(42)$ & $75 \%(102)$ & $74 \%(54)$ & $73 \%(30)$ & $56 \%(18)$ & - \\
\hline Putative PLM sisters & & $0 \%(14)$ & $0 \%(34)$ & $0 \%(18)$ & $0 \%(10)$ & $0 \%(6)$ & - \\
\hline pTU28(uEx4) & mec-3(u6) & \multicolumn{6}{|c|}{ Experiment A } \\
\hline ALM, PLM, and FLPs & & $43 \%(108)$ & $0 \%(18)$ & - & - & - & $0 \%(42)$ \\
\hline Putative PLM sisters & & $6 \%(36)$ & $0 \%(6)$ & - & - & - & $0 \%(14)$ \\
\hline pTU28(uEx4) & $m e c-3(u 6)$ & \multicolumn{6}{|c|}{ Experiment B } \\
\hline ALM, PLM, and FLPs & & $56 \%(30)$ & $22 \%(18)$ & $10 \%(42)$ & $3 \%(30)$ & $0 \%(36)$ & $0 \%(42)$ \\
\hline Putative PLM sisters & & $20 \%(10)$ & $0 \%(6)$ & $0 \%(14)$ & $0 \%(10)$ & $0 \%(12)$ & $0 \%(14)$ \\
\hline pTU28(uEx4) & mec-3(u298) & & & & & & \\
\hline ALM, PLM, and FLPs & & $30 \%(30)$ & $33 \%(30)$ & $2 \%\{42\}$ & $0 \%(18)$ & $0 \%(30)$ & $0 \%(48)$ \\
\hline Putative PLM sisters & & $0 \%(10)$ & $0 \%(10)$ & $0 \%(14)$ & $0 \%(6)$ & $0 \%(10)$ & $0 \%(16)$ \\
\hline pUpsA-Z & mec-3(+) & & & & & & \\
\hline ALM, PLM, and FLPs & & $72 \%(36)$ & $38 \%(24)$ & $50 \%(6)$ & $30 \%(30)$ & $33 \%(6)$ & $40 \%(90)$ \\
\hline Putative PLM sisters & & $0 \%(12)$ & $0 \%|8|$ & $0 \%(2)$ & $0 \%(10)$ & $0 \%(2)$ & $0 \%(30)$ \\
\hline pR123-HS & mec-3(+) & & & & & & \\
\hline ALM, PLM, and FLPs & & $59 \%(54)$ & $77 \%(84)$ & $42 \%(12)$ & $53 \%(30)$ & $54 \%(24)$ & $40 \%(48)$ \\
\hline Putative PLM sisters & & $0 \%(18)$ & $0 \%(28)$ & $0 \%(4)$ & $0 \%(10)$ & $0 \%(8)$ & $0 \%(16)$ \\
\hline \multicolumn{8}{|c|}{ Region I alterations } \\
\hline pRldelA-Z & mec-3(+) & & & & & & \\
\hline ALM, PLM, and FLPs & & $13 \%(30)$ & $21 \%(24)$ & $17 \%(24)$ & $22 \%(18)$ & $17 \%(36)$ & $8 \%(12)$ \\
\hline Putative PLM sisters & & $0 \%(10)$ & $0 \%(6)$ & $0 \%(8)$ & $0 \%(6)$ & $0 \%(12)$ & $0 \%(4)$ \\
\hline pR1delA-Z & $m e c-3(u 6)$ & & & & & & \\
\hline ALM, PLM, and FLPs & & $0 \%(96)$ & $0 \%(48)$ & $0 \%(72)$ & $0 \%(18)$ & - & $0 \%(24)$ \\
\hline Putative PLM sisters & & $0 \%\{32\}$ & $0 \%(16)$ & $0 \%(24)$ & $0 \%(6)$ & - & $0 \%(8)$ \\
\hline pR1A-Z & mec-3(+) & & & & & & \\
\hline ALM, PLM, and FLPs & & $78 \%(42)$ & $70 \%(90)$ & $81 \%(54)$ & $83 \%(30)$ & $78 \%(36)$ & $42 \%(12)$ \\
\hline Putative PLM sisters & & $0 \%(14)$ & $0 \%\langle 30\rangle$ & $0 \%\langle 18\rangle$ & $0 \%\langle 10\}$ & $0 \%(12)$ & $0 \%(4)$ \\
\hline pR1B-Z & mec-3(+) & & & & & & \\
\hline ALM, PLM, and FLPs & & $89 \%(36)$ & $91 \%(66)$ & $67 \%(48)$ & $75 \%(12)$ & $78 \%(18)$ & $72 \%(36)$ \\
\hline Putative PLM sisters & & $0 \%(12)$ & $0 \%(22)$ & $0 \%(16)$ & $0 \%(4)$ & $0 \%\langle 6\rangle$ & $0 \%(12)$ \\
\hline pR1B-Z & $\operatorname{mec}-3(u 6)$ & & & & & & \\
\hline ALM, PLM, and FLPs & & $56 \%(18)$ & $23 \%(30)$ & $14 \%(42)$ & $13 \%(48)$ & - & - \\
\hline Putative PLM sisters & & $0 \%(6)$ & $0 \%(10)$ & $0 \%(14)$ & $0 \%(16)$ & - & - \\
\hline pR1C-Z & mec- $-3(+)$ & & & & & & \\
\hline ALM, PLM, and FLPs & & $42 \%(42)$ & $38 \%(42)$ & $50 \%(12)$ & $17 \%(24)$ & $30 \%(30)$ & $22 \%(18)$ \\
\hline Putative PLM sisters & & $43 \%(14)$ & $21 \%(14)$ & $25 \%(4)$ & $0 \%(8)$ & $0 \%(10)$ & $0 \%(6)$ \\
\hline pR1D-Z & mec-3(+) & & & & & & \\
\hline ALM, PLM, and FLPs & & $83 \%(30)$ & $100 \%(6)$ & $75 \%(12)$ & - & $58 \%(24)$ & $29 \%(54)$ \\
\hline Putative PLM sisters & & $80 \%(10)$ & $100 \%(2)$ & $25 \%(4)$ & - & $0 \%(8)$ & $6 \%(18\}$ \\
\hline pR1E-Z & $\operatorname{mec}-3(+)$ & & & & & & \\
\hline ALM, PLM, and FLPs & & $63 \%(24)$ & $94 \%(48)$ & $61 \%(18)$ & $100 \%(6)$ & $25 \%(12)$ & $83 \%(48)$ \\
\hline Putative PLM sisters & & $25 \%(8)$ & $6 \%(16)$ & $0 \%(6)$ & $0 \%(2)$ & $0 \%(4)$ & $0 \%(16)$ \\
\hline \multicolumn{8}{|c|}{ Region II alterations } \\
\hline pR2-Z & $m e c-3(+)$ & & & & & & \\
\hline ALM, PLM, and FLPs & & $27 \%(60)$ & $2 \%(42)$ & $1 \%(102)$ & $0 \%(36)$ & $0 \%(42)$ & $0 \%(54)$ \\
\hline Putative PLM sisters & & $18 \%(20)$ & $7 \%(14)$ & $3 \%(34)$ & $0 \%(12)$ & $0 \%(14)$ & $0 \%(18)$ \\
\hline pR2-Z & $m e c-3(u 6)$ & & & Experi & t A & & \\
\hline ALM, PLM, and FLPs & & $52 \%(96)$ & $19 \%(36)$ & - & - & - & $3 \%(36)$ \\
\hline Putative PLM sisters & & $32 \%(16)$ & $8 \%(12)$ & - & - & - & $0 \%(12)$ \\
\hline
\end{tabular}

(Table 1 continued on next page) 
Table 1. (Continued)

\begin{tabular}{|c|c|c|c|c|c|c|c|}
\hline \multirow[b]{2}{*}{ Plasmid } & \multirow[b]{2}{*}{$\begin{array}{l}\text { Host } \\
\text { genotype }\end{array}$} & \multicolumn{6}{|c|}{ Stage of development } \\
\hline & & L1 larvae & L2 larvae & L3 larvae & L4 larvae & $\begin{array}{l}\text { young } \\
\text { adult }\end{array}$ & $\begin{array}{l}\text { gravid } \\
\text { adult }\end{array}$ \\
\hline pR2-Z & mec-3(u6) & \multicolumn{6}{|c|}{ Experiment B } \\
\hline ALM, PLM, and FLPs & & $50 \%(66)$ & $36 \%(30)$ & $6 \%(18)$ & $13 \%(24)$ & $13 \%(30)$ & $10 \%(48)$ \\
\hline Putative PLM sisters & & $23 \%(22)$ & $40 \%(10)$ & $33 \%(6)$ & $0 \%(8)$ & $0 \%(10)$ & $6 \%(16)$ \\
\hline \multicolumn{8}{|c|}{ Region I and II alterations } \\
\hline $\mathrm{pRl}+2-\mathrm{Z}$ & mec-3(+) & & & & & & \\
\hline ALM, PLM, and FLPs & & $0 \%(18)$ & $0 \%(42)$ & - & $0 \%(36)$ & $0 \%(18)$ & $0 \%(54)$ \\
\hline Putative PLM sisters & & $0 \%(6)$ & $0 \%(14)$ & - & $0 \%(12)$ & $0 \%(6)$ & $0 \%(18)$ \\
\hline \multicolumn{8}{|c|}{ Region III alterations } \\
\hline pR3-Z (jeEx5) & $m e c-3(+)$ & \multicolumn{6}{|c|}{ Experiment A } \\
\hline ALM, PLM, and FLPs & & $67 \%(66)$ & - & $67 \%(6)$ & $28 \%(18)$ & $28 \%(42)$ & $10 \%(66)$ \\
\hline Putative PLM sisters & & $58 \%(22)$ & - & $0 \%(2)$ & $0 \%(6)$ & $7 \%(14)$ & $5 \%(22)$ \\
\hline $\mathrm{pR} 3-\mathrm{Z}(j e E x 5)$ & $\operatorname{mec}-3(+)$ & \multicolumn{6}{|c|}{ Experiment B } \\
\hline ALM, PLM, and FLPs & & $88 \%(24)$ & $92 \%(24)$ & $55 \%(60)$ & $83 \%(18)$ & $83 \%(6)$ & $6 \%(48)$ \\
\hline Putative PLM sisters & & $50 \%(8)$ & $63 \%|8|$ & $25 \%(20)$ & $16 \%(6)$ & $0 \%\langle 2\rangle$ & $0 \%(8)$ \\
\hline pR3-Z (jeln5) & mec-3(+) & & & & & & \\
\hline ALM, PLM, and FLPs & & $90 \%(72)$ & $79 \%(42)$ & - & $72 \%(18)$ & $33 \%(12)$ & - \\
\hline Putative PLM sisters & & $25 \%(24)$ & $35 \%(14)$ & - & $0 \%(6)$ & $25 \%\{4\rangle$ & - \\
\hline pR3-Z $(j e \ln 5) /+$ & $m e c-3(+)$ & & & & & & \\
\hline ALM, PLM, and FLPs & & $73 \%(90)$ & $43 \%(96)$ & $35 \%(60)$ & $30 \%(30)$ & $0 \%(6)$ & $28 \%(18)$ \\
\hline Putative PLM sisters & & $53 \%(30)$ & $22 \%(32)$ & $0 \%(20)$ & $0 \%(10)$ & $0 \%(2)$ & $0 \%(6)$ \\
\hline \multicolumn{8}{|c|}{ Region IV alterations } \\
\hline pR4delA-Z (jeEx8) & mec-3(+) & \multicolumn{6}{|c|}{ Experiment A } \\
\hline ALM, PLM, and FLPs & & $42 \%(36)$ & $27 \%(54)$ & $25 \%(36)$ & $17 \%(18)$ & $25 \%(12)$ & $26 \%(42)$ \\
\hline Putative PLM sisters & & $75 \%(12)$ & $67 \%(18)$ & $17 \%(12)$ & $17 \%(6)$ & $0 \%(4)$ & $14 \%(14)$ \\
\hline pR4delA-Z (jeEx8) & mec-3(+) & \multicolumn{6}{|c|}{ Experiment B } \\
\hline ALM, PLM, and FLPs & & $50 \%\{108\}$ & $60 \%(36)$ & $26 \%(42)$ & $100 \%(12)$ & - & $38 \%(48)$ \\
\hline Putative PLM sisters & & $69 \%(36)$ & $50 \%(12)$ & $0 \%(14)$ & $50 \%(4)$ & - & $13 \%(16)$ \\
\hline
\end{tabular}

To determine the importance of conserved sequences in the mec-3 $5^{\prime}$ region, deletions and point mutations were introduced into a wild-type mec-3-lacZ fusion plasmid and tested for their effect on expression of $\beta$-galactosidase. These data show that for a wild-type fusion, the frequency of staining cells is approximately constant during development and that the expression of the fusion in extra cells in the tail usually can not be detected. Certain mutant constructions cause a decrease in the frequency of staining cells during development, indicating a defect in maintenance of expression of the fusion. Other constructs give a high frequency of staining of extra cells in the tail, suggesting a defect in repression. mec-3-lacZ fusion plasmids were injected into C. elegans with the Twitcher plasmid pPD10.4l to generate inherited extrachromosomal arrays of these two plasmids. Some extrachromosomal elements were integrated by gamma-ray treatment (see Materials and methods) (jeln-elements), jeEx elements are extrachromosomal. All tested plasmids are part of extrachromosomal elements unless otherwise noted. Transgenic animals were stained with X-gal and scored as described in Materials and methods. Percentages shown represent the sum of the ALM, PLM, and FLP neurons, the mec-3-expressing cells that arise during embryogenesis, divided by the number of such cells that were present (shown in parentheses). When one or two cells in the tail were stained, these were scored as PLM cells. Putative PLM sisters indicates more than two cells and are presumably ALNs (for identification, see Materials and Methods). Certain elements were crossed into the mec-3 mutants $u 6$ or $u 298$ to examine how a lack of mec-3 would affect the expression from a given construct. (-) No animals of this stage were sampled. All of the data shown are from representative observations. Data are shown from two experiments (A and B) to illustrate the degree of variation from one set of observations to the next. jeln5/ + worms were examined to determine whether reduction of plasmid copy number affected expression in PLM sisters. These animals are heterozygous for the integrated jeln 5 element and were generated by crossing a marked jeln 5 strain with N2 males (see Materials and methods). Southern blot analysis indicates that jeln $5 /+$ animals have about one-half as many copies of the mec-3-lacZ fusion as $u E_{X} 4$ animals (see Materials and methods).

whereas the ALNs are in a cluster of neurons in the tail. The additional staining cells in the tail (Fig. 1C) appear to be the ALNs because they can be seen immediately after hatching (data not shown), and because, with the PLMs, these are the only paired cells in the tail that express unc-86 at this time (Finney and Ruvkun 1990). Moreover, staining of more than four cells was never seen, suggesting that the products of the unc-86-requir- ing $\mathrm{T}$ lineage do not express $m e c-3-1 a c Z$ from these constructs (Sulston and Horvitz 1977; Chalfie et al. 1981). Staining of the BDUs, sisters of the ALMs, was not seen in hatched animals. Occasionally, developing embryos with 12 staining cells were observed, but the identities of these cells have not been determined. Staining of the PVD sisters, which undergo programmed cell death, was seen very rarely. For all of the mec-3-lac $Z$ constructs 


\section{pR123-HS}

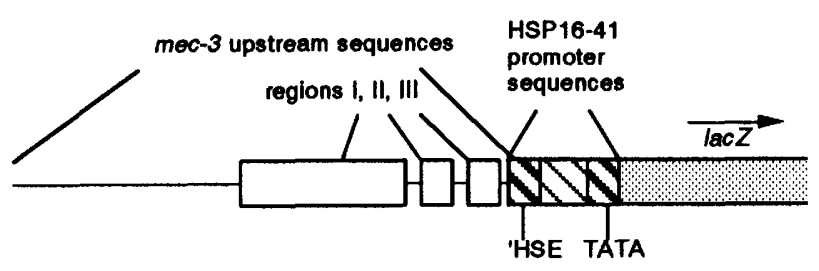

pR1-HS

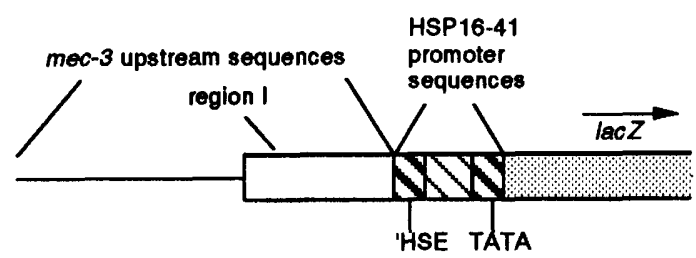

Figure 5. Plasmids carrying mec-3-heat shock hybrid promoters. Plasmids pR123-HS and pR1-HS contain regions I-III and region I, respectively, fused to elements of the heat-inducible $C$. elegans HSP16-41 promoter (Jones et al. 1986). The fusion junction is within the heat shock element. lacZ is fused in-frame to the HSP16-41-coding sequence (E. Stringham and P. Candido, pers. comm.)

that cause expression in extra cells, the ALNs are seen most often, whereas the AIZ and SDQ cells are seen (stained) less often. For example, for animals with pR3-Z, which carries the region III mutant fusion, the population of L1s and L2s shown in Table 1 had staining in 21 of 38 ALNs, 5 of 14 SDQs, and 7 of 38 AIZs.

Staining of presumptive ALN cells in the tail can also be seen in L1 stage larvae carrying $u E x 4$, other extrachromosomal elements carrying pTU28 (the nonmutant mec-3-lac Z fusion), or other constructs with mutations outside of conserved noncoding sequences, although the staining of additional cells is seen at a lower frequency and does not persist as long (Table 1). Expression of $\beta$-galactosidase from wild-type constructs in other sisters of the normal cells is seen in at most $1-10 \%$ of such cells. [Expression of the wild-type fusion in extra cells in mec-3 mutant backgrounds (Table 1 ) is generally within this range and does not suggest that $m e c-3$ plays any role in these cells.] The additional mec-3-expressing cells in the tail probably correspond to the occasional extra mec4(d)-expressing cells in the tail noted by Way and Chalfie (1988). Expression of mec-3-lacZ in additional cells is not the result of increased plasmid copy number in animals carrying mutant mec-3-lac $Z$ fusions (Table 1 ; Materials and methods).

The expression in extra cells is transient, suggesting that expression of the mec-3-lacZ fusion cannot be maintained because mec-3itself is not expressed in these cells. None of the constructs tested caused ectopic mec3-lacZ expression in cells besides sisters of the usual mec-3-expressing cells.

These results indicate that several different sequences must be intact for mec-3 to be repressed in the sisters of the cells that normally express mec-3. Because there is no apparent relationship between these sequences, it may be that distinct proteins must act at various sites in the mec-3 5' region to prevent mec-3 expression in sister cells.

\section{Discussion}

The data presented here indicate that the mec-3 gene contains a large region involved in the initial establishment of mec-3 synthesis, a distinct site necessary for mec-3-dependent maintenance expression, and additional sequences for repression of mec-3 in sisters of cells that normally express this gene (Fig. 4D). These results suggest that the $5^{\prime}$ region of the mec-3 gene controls certain asymmetric cell divisions by allowing mec-3 expression in one of two sister cells and repressing this expression in the other. The lines of evidence supporting these conclusions are as follows:

1. A comparison of the mec-3 sequences from $C$. elegans and $C$. vulgarensis reveals four blocks of conserved noncoding sequence (regions I-IV) upstream from the apparent start codon for the mec-3-coding sequences (Fig. 3A). Because they have been conserved in the course of evolution, these sequences may be important regulatory sites.

2. A large upstream sequence that includes region I and not regions II-IV is necessary for establishment, but not maintenance, of mec-3 expression. When this upstream sequence is coupled to heterologous promoter elements, it can stimulate transcription in mec-3-expressing cells as they arise but not at later times.

3. Alteration of region II causes a defect in maintenance expression of mec-3. Alterations in region I or IV cause other defects but still allow maintenance synthesis of mec-3 while alteration of region III has a slight effect on continued synthesis of a mec-3-lacZ fusion (Table 1).

4. Mutations in regions III, IV, and parts of region I can cause transient expression of a mec-3-lacZ fusion in some sisters of the normal mec-3-expressing cells.

\section{Pattern of mec-3 expression}

mec-3 is expressed in 10 neurons in C. elegans. These neurons share several features: All appear to be mechanoreceptors, and each one is the anterior daughter of an asymmetric cell division. In addition, these cells express the unc- 86 protein, their parent cells express unc-86, and both the mec-3-expressing cells and their sisters are absent in unc-86 mutants (Fig. 2; Chalfie et al. 1981; Way and Chalfie 1989; Finney and Ruvkun 1990). These common features suggest that mec-3 expression may be regulated in the same way in each of the 10 cells that synthesize it.

One way to identify candidate regulatory sequences in a gene is to compare sequences of the gene from two related species. For example, several important regulatory sequences in the Drosophila DOPA decarboxylase 
gene were first identified by comparision of noncoding sequences from Drosophila melanogaster and $D$. virilis (Bray et al. 1988). The nematode strain C. vulgarensis is physically similar to $C$. elegans and has a mec-3 homolog capable of substituting for the mec-3 gene of $C$. elegans. The DNA sequences of $m e c-3$ from each species are similar only in the coding sequence, a region within the $350 \mathrm{bp} \mathrm{5'}$ of the $\mathrm{mec}-3$ start codon, and a small region in the last intron of the gene. The sequences show no other similarity: The introns are different in both length and sequence, suggesting that these two genes have diverged in the course of evolution to the point where only functionally important DNA sequences are conserved.

\section{Establishment and maintenance of mec-3 synthesis}

Previous work defined two modes of mec-3 expression (Way and Chalfie 1989). The initial establishment of mec-3 synthesis is independent of the mec-3 product but requires unc-86. Subsequent expression for the remainder of development is maintained by the mec-3 product. unc-86 may act directly on mec-3: In the lineages that produce mec-3-expressing cells, unc-86 is only expressed a few hours before mec-3 (in Fig. 2, the time between cell divisions is $\sim 2 \mathrm{hr}$ ), and in a large screen for mutants affecting the $C$. elegans touch receptors, no genes were identified that act between unc-86 and mec-3 during touch receptor differentiation (Chalfie and $\mathrm{Au} 1989$ ).

The analysis of the mec-3 promoter presented here has identified cis regions that mediate establishment and maintenance of mec-3. Region I and surrounding sequences mediate establishment of mec-3, so unc-86 may bind to this region. (One candidate site for unc- 86 binding would be the POU consensus site in region I, but mutation of this site alone has no effect on mec-3 regulation.) By the same reasoning, mec- 3 would act through region II. Regions I and II are large enough that several different proteins may bind to these sites, so there may be additional unidentified regulatory proteins necessary for mec-3 establishment and maintenance. Region I may be particularly complex, because it is $71 \mathrm{bp}$, and mutation of some sites within this region leads to expression in the sisters of the normal mec-3-expressing cells.

None of the deletions or mutations examined cause expression of mec-3-lac $Z$ only in a subset of the normal mec-3-expressing cells (legend to Table 1). This would be predicted if mec-3 were sufficient for its own maintenance and there were no subtype-specific factors required for maintenance expression.

\section{Repression of mec-3 synthesis}

Mutational analysis of the mec-3 5 ' region revealed an additional mode of mec-3 regulation: repression in sisters of cells that normally express mec-3 (Table 1; Figs. 1 and 2). Mutations in region I, region III, and deletion of region IV and surrounding sequences can all cause ectopic expression of a mec-3-lacZ fusion in some sisters of the normal mec-3-expressing cells (Table 1 ; Results). This expression is transient, presumably because these additional cells do not express mec-3 itself, and so expression of the fusion is not maintained. Because alteration of several sites can cause this phenotype, the repression process may be complex and could require the action of several proteins at various sites to be complete.

One feature of $C$. elegans development is that asymmetric cell divisions always occur in a given orientation with respect to the rest of the animal (Sulston and Horvitz 1977; Sulston et al. 1983). For example, all mec-3expressing cells are anterior daughters. Several genes necessary for this process have been identified in C. elegans, such as lin-17 (Sternberg and Horvitz 1988), but their molecular function is unknown. The mechanism of such a process cannot be easily extrapolated from an understanding of single-celled organisms such as yeast and E. coli.

Because the mec-3-independent establishment expression of mec-3 is brief, there must be some transiently active regulatory factor present during or immediately after the cell division that produces the mec-3-expressing cells. It is possible that a transient signal such as a cell-cycle regulator could act in combination with cellspecific regulators to actually turn on mec-3. Several groups have found that passage through a particular part of the cell cycle may be necessary for expression of differentiated phenotypes but that cell division itself need not occur (Albertson et al. 1978; White et al. 1982; Edgar and McGhee 1988).

The expression patterns of unc- 86 and mec-3 indicate that unc-86 is always present in a parent cell if one of its descendants expresses mec-3: If a cell expresses unc-86 but never divides, it does not express mec-3 (Fig. 2; Way and Chalfie 1989; Finney and Ruvkun 1990). It may be that in addition to requiring unc-86, establishment synthesis of mec-3 only occurs during a certain part of the cell cycle and cannot take place in a nondividing cell. In this context, it is interesting to note that the sequence CGAAA, which constitutes the common core of the yeast histone and $\mathrm{HO}$ gene cell-cycle regulatory sequences, is found three times in the $150 \mathrm{bp}$ that is conserved in the upstream region of mec-3 [base pairs 16791683, 1707-1711 (region I), and 1959-1963 (3' to region IV) in Fig. 4A; Nasmyth 1985; Osley et al. 1986].

\section{Materials and methods}

Isolation of mec-3 from C. vulgarensis

A genomic $\lambda$ library of DNA from $C$. vulgarensis was obtained from Chris Link (pers. comm.). Several hundred thousand plaques were screened for cross-hybridization to mec-3 by using nick-translated 2.7-kb BamHI fragment from pTU24 as a probe (this fragment contains the last four exons of mec-3). After washing at $37^{\circ} \mathrm{C}$ in $2 \times S S C$, several positive plaques were identified at a frequency of $\sim 1 / 50,000$. Each positive plaque had an apparently identical $3.0-\mathrm{kb}$ EcoRI fragment that cross-hybridized with the C. elegans mec-3 probe. From one such phage, this fragment was subcloned into Bluescript $\mathrm{pKS}(-)$ to yield pJW91-1 and sequenced by standard Sanger/M13 techniques (Fig. 3A; Sanger et al. 1977; Yanisch-Perron et al. 1985).

To verify that the cloned DNA contained a mec-3 homolog 
and not a closely related but functionally different gene, pJW91-1 was coinjected with the "Roller" plasmid pRF4 (Kramer et al. 1990; C. Mello, unpubl., as cited in Liu and Ambros 1991) into mec-3(u6) - after which one of five Roller transformants was touch sensitive-and into mec-3(u298)_from which one of one Roller transformant was touch sensitive and gave rise to a line of touch-sensitive Roller progeny.

Similarities between the $C$. elegans and $C$. vulgarensis sequences were identified by inspection and by computer.

\section{Plasmid constructions}

Most plasmids used in this study are derived from pTU28, a mec-3-lacZ fusion plasmid, or pTU48, which contains intact mec-3 (Way and Chalfie 1989). pJW89-138 was generated by deletion of the internal EcoRI fragments of pTU48; pUpsA-Z is pJW89-138 with the 6-kb XhoI-SalI lacZ fragment from PS118 (Silver et al. 1988) in the unique XhoI site in the mec-3 homeo box. pR4delA-Z and pR $1+2-Z$ were derived from pTU2 28 by deletion of the internal $X b a I$ and NsiI sites, respectively (Table 2). pRIdelA-I is identical to pTU48 with base pairs -1237 to + 1734 removed: pR1D-I (Fig. 4; see below), which has an additional ClaI-digestible site at base pair 1735, was deleted by partial digestion with $C l a \mathrm{I}$ and complete digestion with EcoRV, followed by filling in and ligation. pRIdelA-Z was created from pRldelA-I by insertion of the XhoI-SalI lacZ fragment from PS118 (Silver et al. 1988).

pHS16.25 (E. Stringham and P. Candido, pers. comm.) contains the HSP16-41 promoter region (Jones et al. 1986) in pPD16.51 (Fire et al. 1990), so that the lacZ gene is heat inducible. pR123-HS has the HindIII-XbaI mec-3 fragment containing conserved regions I, II, and III (base pairs 1418-1874) inserted into HindIII- and $\mathrm{XbaI}$-cut pHS16.25: The mec-3 region is immediately upstream of base pair 1266 of HSP16-41, so that pR123-HS includes part of one heat shock element and the heat shock TATA box. pR1-HS is similar and was constructed as follows: the HindIII-Sau3a fragment containing region I of mec-3 (base pairs 1418-1735) was inserted into HindIII and BamHI-digested Bluescript pKS $(+)$, which places an $X b a I$ site adjacent to the Sau3a site; the resulting HindIII-Xbal fragment was inserted into HindIII/XbaI-cut pHS16.25 to generate pR1HS.

\section{Site-directed mutagenesis}

Oligonucleotides for site-directed mutagenesis were designed according to the general principles outlined in Sambrook et al. (1989). As a substrate for mutagenesis, either pTU28 (the intact mec-3-lacZ fusion) or pJW90-19 [pTU24 (Way and Chalfie 1988) with a deletion of $2.7-\mathrm{kb}$ BamHI fragment (base pairs 3121 5661] was used. Because these plasmids have a pIBI30 backbone, they contain an M13/f1 origin of replication/packaging: Each was converted to single-stranded DNA by coinfection with a helper phage. Standard mutagenesis procedures were followed (Sambrook et al. 1989). Mutations generated in pJW90-19 were subsequently transferred into plasmids containing an intact mec-3 gene or mec-3-lacZ fusion by substituting the KpnIBamHI fragment (base pairs 130-3154) for the corresponding fragment of either pJW89-139 (pTU48 with a deletion between $X$ XaI sites at base pairs 1870 and 2489 ) or pR4delA-Z. Several attempts at oligonucleotide mutagenesis of region II all failed, perhaps because this region is very AT-rich and the mutagenic oligonucleotides failed to hybridize with sufficient specificity. Therefore, to mutate region II, a 38-bp Tcl insertion remnant in this site was used (see pTU1 in Way and Chalfie 1988). pR2-I was constructed by insertion of the 2.7-kb BamHI-XmaI mec-3
Table 2. Plasmids used to generate transgenic C. elegans strains

\begin{tabular}{|c|c|c|}
\hline Plasmid & Array & \\
\hline \multicolumn{3}{|c|}{$\begin{array}{c}\text { A. mec-3-lacZ fusion plasmids used to generate } \\
\text { extrachromosomal arrays }\end{array}$} \\
\hline pTU28 & $u E x 4$ & wild-type mec-3-lacZ fusion \\
\hline PTU28 & $j e \ln 2$ & $\begin{array}{l}\text { gamma ray-induced integration of } u E x 4 \\
\text { into a chromosome }\end{array}$ \\
\hline pUpsA-Z & $j e E x 9$ & $\begin{array}{l}\text { pTU28 with deletion from }-213 \text { to } 1494 \\
\text { (upstream nonessential regions) }\end{array}$ \\
\hline pR123-HS & $j e E \times 19$ & $\begin{array}{l}\text { 1418-1874 bp (regions I-III) fused to heat } \\
\text { shock promoter (Fig. 5) }\end{array}$ \\
\hline pR1delA-Z & jeEx20 & $\begin{array}{l}\text { pTU28 with deletion from }-1237 \text { to } 1734 \\
\text { (removes region I; Fig. 4) }\end{array}$ \\
\hline pR1A-Z & $j e E \times 11$ & pTU28 with mutation 1A (region I Fig. 4) \\
\hline pR1B-Z & ieEx21 & pTU28 with mutation 1B (region I; Fig. 4) \\
\hline $\mathrm{pR} 1 \mathrm{C}-\mathrm{Z}$ & $j e E \times 14$ & 8 with mutation $1 \mathrm{C}$ (region I; Fig. 4) \\
\hline pRID-Z & jeEx13 & pTU28 with mutation 1D (region I; Fig. 4) \\
\hline pRIE-Z & jeEx12 & pTU28 with mutation $1 \mathrm{E}$ (region I; Fig. 4) \\
\hline $\mathrm{pR} 2-\mathrm{Z}$ & jeEx6 & pTU28 with Tc1 remnant (region II; Fig. 4) \\
\hline $\mathrm{pRl}+2-\mathrm{Z}$ & jeEx15 & pTU28 with deletion from -1129 to 1810 \\
\hline pR3-Z & jeEx 5 & pTU28 with mutation 3 (region III; Fig. 4) \\
\hline $\mathrm{pR} 3-\mathrm{Z}$ & jeln5-1 & $\begin{array}{l}\text { gamma ray-induced integration of jeEx5 } \\
\text { into a chromosome }\end{array}$ \\
\hline pR4delA-Z & $j e E x 8$ & $\begin{array}{l}\text { pTU28 with deletion from } 1874 \text { to } 2489 \\
\text { (region IV and adjacent sequences) }\end{array}$ \\
\hline \multirow[t]{2}{*}{$\mathrm{pR} 1-\mathrm{HS}$} & $j e E \times 22$ & $\begin{array}{l}1418-1735 \text { bp (region I) fused to heat shock } \\
\text { promoter in pHS16.25 (Fig. } 5 \text { ) }\end{array}$ \\
\hline & \multicolumn{2}{|c|}{$\begin{array}{l}\text { B. Intact mec- } 3 \text { plasmids used to generate } \\
\text { extrachromosomal arrays }\end{array}$} \\
\hline pJW91-1 & jeEx51 & $\begin{array}{l}\text { mec-3 homolog from C. vulgarensis in } \\
\text { pKS }(-)\end{array}$ \\
\hline pTU23 & - & $\begin{array}{l}\text { intact mec-3 plasmid (Way and Chalfie } \\
\text { 1989) }\end{array}$ \\
\hline pTU48 & - & $\begin{array}{l}\text { pTU23 with } \sim 100 \text {-bp deletion in } 3^{\prime} \\
\text { noncoding sequences (Way and Chalfie } \\
1989 \text { ) }\end{array}$ \\
\hline pRIB-I & jeEx58 & mutation 1B in pTU48 (region I; Fig. 4) \\
\hline pRIE-I & jeEx57 & mutation $1 \mathrm{E}$ in pTU48 (region I; Fig. 4) \\
\hline pR2-I & jeEx62 & $\begin{array}{l}\text { Contains } 125-5661 \text { bp with Tcl remnant } \\
\text { in region II (Fig. 4) }\end{array}$ \\
\hline pR3-I & jeEx56 & mutation 3 in pTU48 (region III; Fig. 4) \\
\hline
\end{tabular}

Plasmids and corresponding extrachromosomal elements. mec-3-lacZ fusion plasmids were injected into wild-type C. elegans (N2) with the antisense unc-22 plasmid pPD10.41, which confers a dominant Twitcher phenotype (Fire et al. 1990). Intact mec-3 plasmids were injected into mec-3(u6) with the plasmid pRF4, which confers a dominant Roller phenotype. Some of these extrachromosomal arrays were derived from injections described in Fig. 4D. Extrachromosomal arrays are named according to standard C. elegans nomenclature: (jeEx) Elements are extrachromosomal arrays generated by microinjection of DNA and behave as unstable free duplications; (jeln) elements are integrated into a chromosome and are therefore stable. Sequence numbers refer to the mec-3 sequence of Way and Chalfie (1988). From the comparison of the C. elegans and $C$. vulgarensis mec-3 sequences (Fig. 4A), the apparent start of C. elegans mec-3 translation is at $2021 \mathrm{bp}$.

homeo box-containing fragment from pTU25 into BamHI- and XmaI-digested pTU1 (Way and Chalfie 1988); this plasmid is analogous to other intact mec-3 plasmids except that it lacks base pairs -1237 to +125 . pR2-Z was constructed in the same manner as site-directed mutant mec-3-lacZ fusion plasmids.

\section{C. elegans strains, constructions, and injections and staining}

C. elegans strains were handled as described by Wood (1988). General properties of $m e c$ mutants are described in Chalfie and 
Au (1989). The mec-3 mutant U298 contains a transposon Tcl insertion in region II of the mec-3 5' region (Way and Chalfie 1988; this study). $u 6$ is one of several ethylmethane sulfonate (EMS)-induced mutations in mec-3 (Chalfie and Au 1989). All mec-3 mutations tested cause a reduction, but not elimination, of expression of a mec-7-lacZ fusion. $u 298$ causes the mildest reduction, whereas $u 6$ causes the most severe reduction (M. Hamelin, I. Scott, J. Way, and J. Culotti, in prep.). It is not known whether any existing alleles are null. The unc-86 alleles $n 846$ (null) and $n 848$ (ts) are described by Finney and Ruvkun (1990) and Finney (1987).

jeln2 is an insertion of the $u E x 4$ element into the unc-22 region of chromosome IV. This insertion was generated by gamma ray treatment (C. Kari, A. Fire, and R. Herman, pers. comm.): Twenty $u E x 4$ L4-stage animals were treated with 3800 rads from a ${ }^{137} \mathrm{Cs}$ source and placed on separate plates. From the 8 animals that had normal broods, a total of $107 \mathrm{~F}_{1} u E \times 4$ progeny were picked to individual plates. From each of the $56 \mathrm{~F}_{1}$ animals with normal-brood sizes, $3 \mathrm{~F}_{2}$ animals were picked to separate plates and examined for the failure to segregate nonuEx4 animals. Two such independent isolates were identified, jeln2 and jeln3. jeln2 was outcrossed once to eliminate an unlinked temperature-sensitive sterility. jeln 5 and jeln 8 were constructed in a similar manner from jeEx5 and $j e E x 8$, respectively. Their chromosomal locations are unknown.

C. elegans strains were injected according to Fire (1986). Sometimes animals were injected in the gonad syncitium, which was convenient for generating large numbers of animals that were transformed for one generation. mec-3-lac $Z$ fusions were coinjected with the "Twitcher" plasmid pPD10.41 (Fire et al. 1990) into the N2 strain, whereas intact mec-3 plasmids were coinjected with the Roller plasmid that carries the rol-6 gene with the dominant mutation su1006 (Kramer et al. 1990; C. Mello and V. Ambros, unpubl. as cited in Liu and Ambros 1991) into $u 6$ or $u 298$.

\section{Interpretation of $X$-gal staining}

C. elegans strains carrying lac $Z$ fusions were stained for $24 \mathrm{hr}$ at $37^{\circ} \mathrm{C}$ according to Way and Chalfie (1989) and Fire et al. (1990). As described in Way and Chalfie (1989), in adult $u E x 4$ animals two neurons in the head (probably the AIZ cells), several motor neurons in the posterior ventral cord, and occasional intestinal cells can express $\beta$-galactosidase activity. This expression may be artifactual, as none of these cells is known to be affected by mec- 3 mutations. Because $\beta$-galactosidase activity is seen long after these cells are produced, the control of lacZ expression must be different in these cells than it is in the 10 canonical mec-3-expressing cells. Most of the constructs do not affect this expression, and it has not been investigated in detail.

Not all of the canonical mec-3-expressing cells express the $m e c-3-1 a c Z$ fusion in animals carrying jeln2, as detected in our standard assay. This is probably because the level of $\beta$-galactosidase activity in these cells is near the threshold of detectability with this assay and not because these cells are differentiating incorrectly. When animals carrying $u E x 4$ or jeln 2 are grown at $25^{\circ} \mathrm{C}$ instead of $20^{\circ} \mathrm{C}$, almost $100 \%$ of the mec-3-expressing cells show $\beta$-galactosidase activity, and growth at $15^{\circ} \mathrm{C}$ causes $\beta$-galactosidase activity to be low (Way and Chalfie 1989; unpubl.). Because these temperature conditions are not known to affect touch receptor differentiation, it would appear that synthesis or stability of $\beta$-galactosidase is somewhat temperature sensitive in C. elegans and that expression of lacZ from the mec-3 promoter at $20^{\circ} \mathrm{C}$ gives levels of $\beta$-galactosidase activity near the threshold of detection. The apparent variation from cell to cell in activity levels may be the result of variations in fixation. No attempt is made to quantify differences in staining intensity: Each cell is scored as staining or not staining. To be considered stained, a cell must be distinctly blue.

Transgenic C. elegans strains were examined by Southern blot to determine whether different staining patterns could be explained by variations in plasmid copy number within different arrays. The $u E x 4$ element contains $\sim 40$ copies per cell of both pTU28 and pPD10.41 (Way and Chalfie 1989). Compared with a $u E x 4$ strain, strains carrying pR2-Z, pR3-Z, or pR4delA-Z did not have fewer copies of the mec-3-lac $Z$ fusion plasmid, whereas the copy number of pUpsA-Z in jeEx 9 is $\sim 10$-fold lower than that of pTU28 in $u E x 4$ (data not shown). Southern analysis indicates that $u E x 4$ and jeIn5, respectively, contain about five and four times as many copies of the mec-3-lacZ fusion as does jeln2. In spite of these differences, $j e \ln 2$ and $u E x 4$ strains have the same overall staining pattern, as do jeEx5, $j e \ln 5$, and jeln $5 /+$ strains. Also, jeln $5 /+$ animals carry fewer copies of the mec-3-lacZ fusion than animals carrying $u E x 4$; however, in spite of this, jeln $5 /+$ animals show $\beta$-galactosidase activity in sisters of the normal mec-3-expressing cells, and $u E x 4$ animals do not. It is thus unlikely that this ectopic expression is the result of variations in copy number of the mec3-lacZ fusion in different transgenic lines. jeln5/+ animals were generated by constructing a unc-24(e138) mec-17(u265) mec-3(u467) dpy-20(e1282); jeln5 strain, then mating with N2 males, and picking non-Unc, non-Dpy animals to be stained.

\section{Acknowledgments}

We thank Pamela Silver, Iva Greenwald, Richard Padgett, Gary Ruvkun, Mike Finney, Mark Osborne, and Mark Peifer for reading the manuscript; Jie Zhang for construction of jeln2; Chris Link for the C. vulgarensis genomic library; Peter Candido and Eve Stringham for pHS16.25; Pamela Silver for providing the laboratory environment during the initiation of these experiments; and Michel Hamelin, Joe Culotti, and Andrew Fire for discussion of unpublished results. Some nematode strains used in this work were provided by the Caenorhabditis Genetics Center, which is funded by the National Institutes of Health (NIH) National Center for Research Resources. This work was supported by a Merck postdoctoral fellowship and NIH FIRST Award R29-25557.

The publication costs of this article were defrayed in part by payment of page charges. This article must therefore be hereby marked "advertisement" in accordance with 18 USC section 1734 solely to indicate this fact.

\section{Note added in proof}

Sequence data described in Fig. 3 have been submitted to the EMBL/GenBank data libraries.

\section{References}

Albertson, D.G., J.E. Sulston, and J.G. White. 1979. Cell cycling and DNA replication in a mutant blocked in cell division in the nematode Caenorhabditis elegans. Dev. Biol. 63: 165178.

Bell, L. R., E.M. Maine, P. Schedl, and T.W. Cline. 1988 Sexlethal, a Drosophila sex determination switch gene, exhibits sex-specific RNA splicing and sequence similarity to RNA binding proteins. Cell 55: 1037-1046.

Bray, S.J., W.A. Johnson, J. Hirsh, U. Heberlein, and R. Tijian, R. 1988. A cis-acting element and associated binding factor re- 
quired for CNS expression of the Drosophila melanogaster DOPA decarboxylase gene. EMBO I. 7: 177-188.

Chalfie, M. and M. Au. 1989 Genetic control of differentiation of the Caenorhabditis elegans touch receptor neurons. Science 243: 1027-1033.

Chalfie, M., H.R. Horvitz, and J.E. Sulston. 1981. Mutations that lead to reiterations in the cell lineages of $C$. elegans. Cell 24: 59-69.

Driscoll, M. and M. Chalfie. 1991. The mec-4 gene is a member of a family of Caenorhabditis elegans genes that can mutate to induce neuronal degeneration. Nature 349: 588-593.

Edgar, L. and J. McGhee. 1988. DNA synthesis and the control of embryonic gene expression in C. elegans. Cell 53: 589599.

Finney, M. 1987. "The genetics and molecular biology of unc86, a C. elegans cell lineage gene." Ph.D. thesis, Massachusetts Institute of Technology, Cambridge, MA.

Finney, M. and G. Ruvkun. 1990. The unc-86 product couples cell lineage and cell identity in C. elegans. Cell 63: 895-905.

Fire, A. 1986. Integrative transformation of Caenorhabditis elegans. EMBO f. 5: 2673-2680.

Fire, A., S.W. Harrison, and D. Dixon. 1990. A modular set of lacZ fusion vectors for studying gene expression in Caenorhabditis elegans. Gene 93: 189-198.

Freyd, G., S.K. Kim, and H.R. Horvitz. 1990. Novel cysteine-rich motif and homeodomain in the product of the Caenorhabditis elegans cell lineage gene lin-11. Nature 344: 876-879.

Jones, D., R.H. Russnak, R.J. Kay, and E.P.M. Candido. 1986. Structure, expression and evolution of a heat shock gene locus in Caenorhabditis elegans that is flanked by repetitive elements. I. Biol. Chem. 261: 12006-12015.

Kakidani, H. and M. Ptashne. 1988. Gal4 activates gene expression in mammalian cells. Cell 52: 161-167.

Karlsson, O., S. Thor, T. Norberg, H. Ohlsson, and T. Edlund. 1990. Insulin gene enhancer binding protein Isl-1 is a member of a novel class of proteins containing both a homeodomain and a Cys-His domain. Nature 344: 879-882.

Kramer, J.M., R.P. French, E.-C. Park, and J.J. Johnson. 1990. The Caenorhabditis elegans rol-6 gene, which interacts with the $s q t-1$ collagen gene to determine organismal morphology, encodes a collagen. Mol. Cell. Biol. 10: 2081-2089.

Liu, Z. and V. Ambros. 1991. Alternative temporal control systems for hypodermal cell differentiation in Caenorhabditis elegans. Nature 350: 162-165.

Nasmyth, K. 1985. A repetitive DNA sequence that confers cell-cycle START (CDC28)-dependent transcription of the HO gene in yeast. Cell 42: 225-235.

Osley, M.A., J. Gould, S. Kim, M. Kane, and L. Hereford. 1986. Identification of sequences in a yeast histone promoter involved in periodic transcription. Cell 45: 537-544.

Ptashne, M. 1987. A genetic switch: Gene control and phage lambda. Blackwell Scientific Publishing. Palo Alto, CA.

Ruvkun, G. and M. Finney. 1991. Regulation of transcription and cell identity by POU domain proteins. Cell 64: 475-478.

Sambrook, J., E.F. Fritsch, and T. Maniatis. 1989. Molecular cloning: A laboratory manual, 2nd ed. Cold Spring Harbor Laboratory Press, Cold Spring Harbor, New York.

Sanger, F., S. Nicklen, and A. Coulson. 1977. DNA sequencing with cahin-terminating inhibitors. Proc. Nat. Acad. Sci. 81: 4018-4022.

Savage, C., M. Hamelin, J.G. Culotti, A. Coulson, D.G. Albertson, and M. Chalfie. 1989. mec-7 is a $\beta$-tubulin gene required for the production of 15 protofilament microtubules in Caenorhabditis elegans. Genes \& Dev. 3: 870-881.

Silver, P., A. Chiang, and I. Sadler. 1988. Mutations that alter both localization and production of a yeast nuclear protein.
Genes \& Dev. 2: 707-717.

Sternberg, P. and H.R. Horvitz. 1988. lin-17 mutations of Caenorhabditis elegans disrupt certain asymmetric cell divisions. Dev. Biol. 130: 67-73.

Sulston, J. and H.R. Horvitz. 1977. Post-embryonic cell lineages of the nematode Caenorhabditis elegans. Dev. Biol. 56: $110-156$.

Sulston, J.E., E. Schierenberg, and J.G. White, J.N. Thomson. 1983. The embryonic cell lineage of the nematode Caenorhabditis elegans. Dev. Biol. 100: 64-119.

Way, J.C. 1990. Determination of cell type in the nervous system. Sem. Neurosci. 2: 173-184.

Way, J.C. and M. Chalfie. 1988. mec-3, a homeobox-containing gene that specifies differentiation of the touch receptor neurons in C. elegans. Cell 54: 5-16.

- 1989. The mec-3 gene of Caenorhabditis elegans requires its own product for maintained expression and is expressed in three neuronal cell types. Genes \& Dev. 3: 18231833.

Webster, N., J.R. Jin, S. Green, M. Hollis, and P. Chambon. 1988. The yeast $\mathrm{UAS}_{\mathrm{G}}$ is a transcriptional enhancer in human HeLa cells in the presence of the GAL4 trans-activator. Cell 52: 169-178.

White, J.G., H.R. Horvitz, and J.E. Sulston. 1982. Neurone differentiation in cell lineage mutants of Caenorhabditis elegans. Nature 297: 584-587.

Wolinsky, E. and J. Way. 1990. The behavioral genetics of Caenorhabditis elegans. Behav. Genet. 20: 169-189.

Wood, W.B., ed. 1988. The nematode Caenorhabditis elegans. Cold Spring Harbor Laboratory, Cold Spring Harbor, New York.

Yanisch-Perron, C., J. Vieira, and J. Messing. 1985. Improved M13 phage cloning vectors and host strains: nucleotide sequences of the M13 mpl 8 and pUC19 vectors. Gene 33: 103119. 


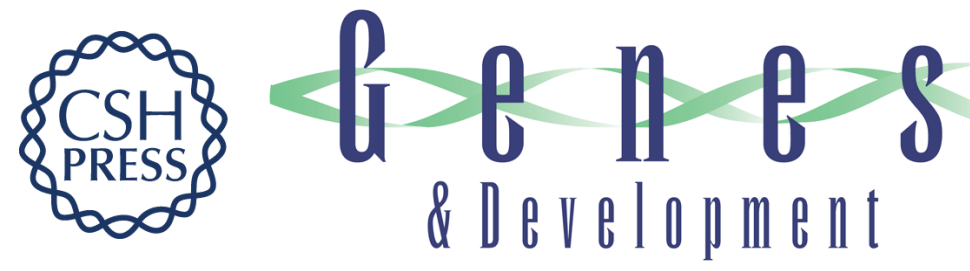

\section{The mec-3 gene contains cis-acting elements mediating positive and negative regulation in cells produced by asymmetric cell division in Caenorhabditis elegans.}

J C Way, L Wang, J Q Run, et al.

Genes Dev. 1991, 5:

Access the most recent version at doi:10.1101/gad.5.12a.2199

References This article cites 32 articles, 6 of which can be accessed free at:

http://genesdev.cshlp.org/content/5/12a/2199.full.html\#ref-list-1

License

Email Alerting Receive free email alerts when new articles cite this article - sign up in the box at the top Service right corner of the article or click here.

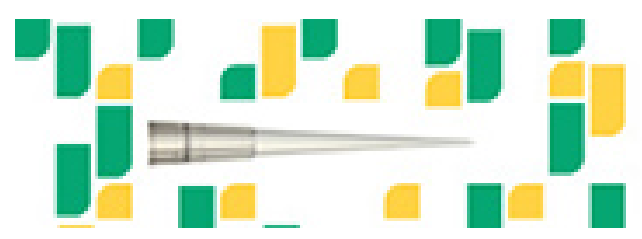

Focused on your science. 